\title{
The Discourse Analysis of E-Business Instant Communication from the Perspective of Politeness Principle
}

\author{
Tingting Guo ${ }^{1,2}$ \& Zhenxia Zhao ${ }^{1,3}$ \\ ${ }^{1}$ School of Foreign Languages, Zhongyuan University of Technology, Zhengzhou, Henan, China \\ ${ }^{2}$ School of Liberal Arts, Zhengzhou University, Zhengzhou, Henan, China \\ ${ }^{3}$ School of International Business, Southwestern University of Finance and Economics, Chengdu, Sichuan, China \\ Correspondence: Tingting Guo, Zhongyuan University of Technology, No. 41, Middle Zhongyuan Road, \\ Zhengzhou 450007, China. E-mail: 532955649@qq.com
}

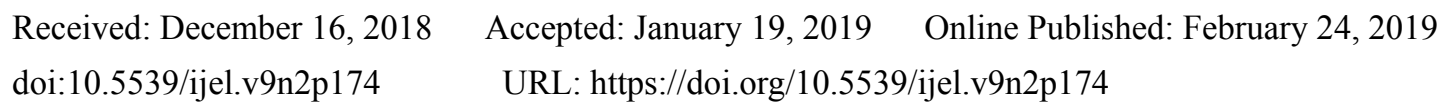

\begin{abstract}
With the popularity and frequency of e-business activities, e-business instant communication plays an increasingly important role in e-business, and the appropriate and reasonable use of business language usually directly influences the economic interests. Therefore, the present study takes politeness principle as the theoretical framework and the participants' chat records of e-business instant communication as the research data, and adopts the methodologies of discourse analysis and interview to explore the language use in e-business activities from the perspective of politeness principle. And the present study finds that servicers and customers use different linguistic resources from the perspective of politeness principle out of different interest pursuit. More specifically, servicers strictly observe the six maxims having no violations in e-business instant communication, while customers go against Tact Maxim, Generosity Maxim, Approbation Maxim and Modesty Maxim and usually comply with Agreement Maxim and Sympathy Maxim, nevertheless, they violate Agreement Maxim and Sympathy Maxim on special occasion in e-business instant communication. What's more, if customers can strictly observe Agreement Maxim and Sympathy Maxim, and servicers can study how to avoid and deal with customers' violation to Agreement Maxim and Sympathy Maxim successfully, enterprises, servicers and customers will benefit.
\end{abstract}

Keywords: politeness principle, e-business instant communication, discourse analysis

\section{Introduction}

With the rapid development of economy and network technology, e-business activities are becoming more and more frequent and popular, the competitions among e-business providers are getting fiercer, and the relationship between the e-business providers and customers is becoming increasingly complex. Because language urges people to communicate, e-business activities can't be separated from language (Felemban, 2012; Grice, 1975), in other words, e-business instant communication plays an increasingly important role in e-business. Furthermore, the appropriate and reasonable use of business language usually directly determines the success or failure of e-business communications, and further influences the economic interests. Therefore, it is necessary to adopt the method of discourse analysis and interview to analyze the discourses of e-business instant communication from the perspective of politeness principle, and further reflect the vital function of appropriate use of politeness principle in business activities and facilitate the exertion of the politeness principle in business activities by both parties so as to improve the quality of service, promote the achievement of trade, increase the developmental efficiency of e-business and economy and finally make both enterprises and customers beneficial. The research's theoretical significance is to enrich the application of politeness principle and discourse analysis. And its practical significance is to strengthen the use of politeness principle in e-business instant communication and further make both enterprises and customers beneficial.

\section{Literature Review}

The key concepts, namely, politeness principle, e-business instant communication and discourse analysis, used in the present study and previous studies on them are analyzed and presented in this part. 


\subsection{Politeness Principle}

The politeness principle was raised by Leech, a British linguist, to "make up for the lack of cooperative principle" (Gu, 1992; Sun \& Tian, 2012). Politeness principle means that in the communicative activities, the level of politeness and the consciousness of thinking for others should be raised to the maximum, and the sense of harming to others should be minimized.

According to the studies on politeness principle in both domestic and overseas, we can find that most scholars put emphasis on politeness principle itself, such as Levinson (1983), the application of the politeness principle in cross-cultural and business communication (e.g. Holgraves \& Joong-nam, 1990), the exertion of politeness principle in language teaching and learning and the combination of politeness principle with cooperative principle and other linguistic principles, such as Lin, 2011; Shen, 2013; Ma \& Zhao, 2007; Zhou, 2007; Wu, 2003. However, quite a few scholars pay attention to the application of politeness principle in e-business activities and e-business instant communication - the concrete exertion of the six principles of politeness principle in e-business activities and e-business instant communication. Therefore, this study starts from the perspective to analyze the specific exertion of politeness principle in e-business instant communication.

\subsection{E-business Instant Communication}

The instant communication is "a kind of terminal service which allows two or more people to transfer text messages, files, audios and videos in real time via internet" (Wan, 2016). And e-business instant communication mainly refers to the application of instant communication in e-business, such as Alitalk, which is conductive to the communication among servicers and customers and further smooth the trade.

\subsection{Discourse Analysis}

The discourse is "a specific verbal act of communication among people, and a verbal activity of communication between a certain speaker and a subject in a particular social context, including speakers, subjects, text, communication, context and other elements. And discourse analysis is a study on what people say (narrate), how to say it, and the social consequences of what they say" (Huang, 2006). And Lin (2007) pays attention to the records of the language and expression of the chat room of the Alitalk. Similarly, the present study focuses on the discourse analysis of e-business instant communication.

With regard to the relationship between instant communication and e-business, most scholars often study the use of tools of e-business instant communication in business activities, especially in e-business activities, such as Lin (2007) and Wan (2016). But few scholars analyze the effects of the language of instant communication and the application of specific signs of communication in business activities, for instance, Wan (2016) analyzes the advantages of instant communication tools in network marketing and studies the application of instant communication tools in various e-business websites, and further concludes that the application of instant communication tools can help improve the success rate of transaction between enterprises and customers. Moreover, Lin (2007) argues that e-business websites can build good relationships between enterprises and customers and achieve excellent online sales results via instant communication software by describing the current status and trends of the development of instant communication tools, including the current status and trends of instant communication tools in the global marketplace and in the Chinese market, and analyzing specific cases, such as, C2C, B2B, B2C and other applications of instant messaging software in e-business.

The discourse analysis is not only a discipline but also an analytical tool. Many studies focus on the development, classification and the application of discourse analysis in specific context as an analytical tool (e.g. Huang, 2006; Zhu, 2003; Brown, Gillian, \& Yule, 1983). And Zhu (2003) reviews the development of discourse analysis in the past years and the achievements, characteristics and deficiencies at different stages of development.

\section{Theoretical Framework and Methodology}

In this part, the present study explains the connotation of the politeness principle considered as the theoretical framework and the research methodology which includes research objective, research questions and data collection.

\subsection{Politeness Principle}

The politeness principle mentioned by Leech and considered as the theoretical framework contains six criteria, each of which has two norms. The first criterion is the Tact Maxim meaning to minimize the adverse information to others and benefit others as much as possible. The second criterion is the Generosity Maxim meaning to minimize the information of self-interest and benefit oneself less. The third criterion is the Approbation Maxim meaning to minimize accusations against others and praise others as much as possible. The fourth criterion is the 
Modesty Maxim meaning to minimize the praise to self and criticize self as much as possible. The fifth criterion is the Agreement Maxim meaning to minimize disagreement with others and agree with others as much as possible. The sixth criterion is the Sympathy Maxim meaning to minimize opposition to others and maximize the mutual understanding (Leech, 1983). Because each criterion can be involved in the discourses of e-business instant communication, this study analyzes the discourses of e-business instant communication from these six criteria respectively.

\subsection{Research Methodology}

The present study takes politeness principle as the theoretical framework and the chat records of the participants of e-business instant communication as the research data, and adopts the methodologies of discourse analysis and interview to explore the language use in e-business activities from the perspective of politeness principle. Then, the research objective, research questions and data collection are elaborated in this part.

\subsubsection{Research Objective}

The research objective is to facilitate the exertion of politeness principle in e-business activities by both parties so as to improve the quality of service, promote the achievement of trade, increase the developmental efficiency of the e-business and economy and finally make both enterprises and customers beneficial through analyzing how the application of politeness principle affects the communication between servicers and customers in the e-business instant messaging software chat rooms and further affecting the efficiency and success rate of e-business activities.

\subsubsection{Research Questions}

If the above-mentioned research objective is to be achieved, the present study should clarify some questions first. The concrete questions to be explored are as follows:

1) What are the results of customer service staffs and customers observing politeness principle?

2) What are the results of customer service staffs and customers violating politeness principle?

3) How does the application of politeness principle influence the transaction?

\subsubsection{Data Collection}

The data analyzed and discussed in this thesis are chat records of customers when they do pre-consultation or after-sales service and servicers, which occur in the e-business instant messaging software chat rooms in the most unaffected situation, express both parties' real opinions and true feelings, and are presented in the form of screen-shots of the smart phone. And the database includes 459 pieces of screen-shots of chat records coming from 73 participants (49 women and 24 men from different occupations and ages) and some representatives will be presented in the thesis. What's more, the present study carefully analyzes the collected data and selects those data that are conductive to the study at first. And then, the present study further subdivides the selected data into discourses of servicers' conformation to politeness principle in e-business instant communication, discourses of customers' conformation to politeness principle in e-business instant communication, discourses of servicers' violation to politeness principle in e-business instant communication and discourses of customers' violation to politeness principle in e-business instant communication. Finally, the present study classifies these subdivided discourses according to the six criteria of politeness principle.

\section{Use of Politeness Principle in E-Business Instant Communication}

In this part, the present study respectively analyzes the expression of servicers' and customers' discourses observing and violating politeness principle.

\subsection{Discourse Analysis of Servicers' Conformation to Politeness Principle}

In this section, the present study respectively analyzes the expression of servicers' discourses conformation to politeness principle's six maxims in the following sequence: Tact Maxim, Generosity Maxim, Approbation Maxim, Modesty Maxim, Agreement Maxim, Sympathy Maxim through analyzing the concrete examples.

\subsubsection{Servicers' Conformation to the Tact Maxim}

First of all, the Tact Maxim means people who observe politeness principle will try their best to minimize disadvantageous information to others and benefit others as much as possible. In other words, what servicers do or say is in customers' shoes, considers the gain and loss of customers and finally satisfies customers. 
Example 1:

\begin{tabular}{|c|c|c|}
\hline Message number & Text & Translation \\
\hline 1 & $\begin{array}{l}\text { Servicer: } \\
\text { 您 } 14.6 \text { 寸电脑屏幕外壳是比较大的吗 }\end{array}$ & $\begin{array}{l}\text { Servicer: } \\
\text { Is the screen enclosure of your computer whose screen is } 14.6 \\
\text { inches relatively large? }\end{array}$ \\
\hline 2 & $\begin{array}{l}\text { Servicer: } \\
\text { 亲, 这个是设计尺寸, 和成包尺寸不同 } \\
\text { 的, 成包要大一点 }\end{array}$ & $\begin{array}{l}\text { Servicer: } \\
\text { Darling, this is the design size different from the package size which } \\
\text { is bigger. }\end{array}$ \\
\hline 3 & $\begin{array}{l}\text { Customer: } \\
\text { 我的意思是 }\end{array}$ & $\begin{array}{l}\text { Customer: } \\
\text { I mean }\end{array}$ \\
\hline 4 & $\begin{array}{l}\text { Customer: } \\
\text { 我现在 } 14.6 \text { 的电脑放不进去 }\end{array}$ & $\begin{array}{l}\text { Customer: } \\
\text { The laptop bag I have bought in your shop can't contain my } \\
\text { computer which is } 14.6 \text { inches. }\end{array}$ \\
\hline 5 & $\begin{array}{l}\text { Servicer: } \\
\text { 亲, 如果您觉得电脑放不下影响使用, } \\
\text { 您可以考虑换一款, 或者退货哦 }\end{array}$ & $\begin{array}{l}\text { Servicer: } \\
\text { Dear, if you think the laptop bag is too small to contain your } \\
\text { computer, you can change it to another model or choose to return it. }\end{array}$ \\
\hline 6 & $\begin{array}{l}\text { Customer: } \\
\text { 有比这大的嘛 }\end{array}$ & $\begin{array}{l}\text { Customer: } \\
\text { Are there some bigger than it? }\end{array}$ \\
\hline
\end{tabular}

As shown in example 1, when the commodity, bought by the customer, isn't satisfying and the customer is planning to complain, the servicer steps up and offers all possible solutions, like sentence 5. Moreover, the servicer also uses the cute modal particles, such as "oh", which not only can ease the embarrassing condition and bring the customer closer to the servicer, but also can further facilitate the conclusion of the transaction and resolution of the conflict.

For verifying what we have talked about, the author has interviewed those customers whose shopping experience has been selected as the typical cases.

...I was really angry about that for my being anxious for using laptop bag. But when I saw the servicer's message, I felt that the servicer had thought a lot of my best interests, and I changed my mind taking a more peaceful way to settle the matter. Even more surprising, with the enthusiastic assistance and careful guidance of the servicer, I changed it for another laptop bag which was delicate with proper size... [Mr. Zhang]

In a word, although there are many unexpected situation in the process of trading, the transactions will be conducted more smoothly with the Tact Maxim taken by the servicers.

\subsubsection{Servicers' Conformation to the Generosity Maxim}

Secondly, the Generosity Maxim means people who observe politeness principle will try their best to minimize advantageous information to self and benefit self as little as possible. In other words, what servicers do or say isn't in their own shoes, doesn't consider the gain and loss of themselves and finally satisfies customers and further closes the deal smoothly. As a matter of fact, the Generosity Maxim has the same effect with the Tact Maxim when used - carry on transactions with principle making customers benefit a lot and letting servicers gain little.

Example 2:

\begin{tabular}{lll}
\hline Message number & Text & Translation \\
\hline 1 & Customer: & Customer: \\
& 售前咨询 & Pre-consultation \\
& Customer: & Customer: \\
3 & 你好 & Hello \\
& Customer: & Customer: \\
4 & 三十多的东西质量怎么样 & How about the quality of commodity costing more than 30 RMB? \\
& Customer: & Customer: \\
& 有味道吗 & Are there some peculiar smells? \\
& Servicer: & Servicer: \\
& 你好, 刚穿起来会有一点味道, 马 & Hello, there indeed are some peculiar smells at the beginning of the using of \\
& 上就没有了 & the clothes, but the peculiar smells will disappear quickly. \\
& Servicer: & Servicer: \\
& 质量问题和运输破损的, 坏了包换 & If there are some damages caused during the transportation and quality \\
& & problems, you can change it for free. \\
\hline
\end{tabular}


As shown in example 2, the servicer strictly observes the Generosity Maxim-when the customer asks the quality of the commodity, the servicer doesn't praise the commodity and says it is perfect, but strictly observes the Generosity Maxim like sentence 5.

...Because I worried about the quality of the commodity at the quite low price, I just tried to ask. But I was surprised that the servicer was honest, hahaha. He told me that there indeed are some peculiar smells at the beginning of the using of the clothes, but the peculiar smells will disappear quickly. I believed what the servicer said and bought one, and the fact proved that the servicer and I were right...I think I will buy things I need in this shop again for their honesty... [Mr. Wang]

On the surface, the servicer exposes the shortcomings of the commodity to the customer, however, the servicer who lets the customer know the commodity clearly and feel the honesty of the servicer is the true beneficiary.

\subsubsection{Servicers' Conformation to the Approbation Maxim}

Thirdly, the Approbation Maxim means people who observe politeness principle will try their best to minimize criticism to other people and pay other people compliments as much as possible. In other words, even if there are some problems caused by errors or omissions of customers, servicers should be magnanimous and good-mannered containing customers' faults and errors and not bothering about too much of the gain and loss. What's more, it will be better if the servicers can praise the customers at a proper moment.

Example 3:

\begin{tabular}{lll}
\hline Message number & Text & Translation \\
\hline 1 & Servicer: & Servicer: \\
& 您好 & Hello \\
& Customer: & Customer: \\
& 刚付了款 & I just paid the bill. \\
3 & Customer: & Customer: \\
& 忘记备注袜子的颜色了 & But I have forgotten to note the color of the socks. \\
4 & Customer: & Customer: \\
& 表情符号/大哭 & Emoticon/Cry \\
5 & Servicer: & Servicer: \\
& 颜色发我 & You can send the color to me. \\
6 & Customer: & Customer: \\
& 两白两黑一墨绿 & I want two pairs of white socks, two pairs of black socks and a pair of dark green socks. \\
& Customer: & Customer: \\
& 谢谢, 实在麻烦了 & Thank you and I'm so sorry to bother you. \\
& Servicer: & Servicer: \\
\hline & 好的没事 & Well, nothing. \\
\hline
\end{tabular}

...I was very sorry to bother the servicer and worried about the color I wouldn't like. However, the servicer was friendly for which I had a wonderful shopping experience and also gave this shop a five-star high praise... [Ms. Liang]

From example 3, we can find that although the problems caused by errors or omissions of customers has caused trouble to servicers, such as noting error message and forgetting to note message, etc., the servicers don't find faults with or complain the customers, but help the customers correct the mistakes heartily and further facilitate the completion of the deal successfully. As a result, the customer has a wonderful shopping experience in this shop, and the servicers and the merchants likewise get returns because of their favorable attitudes and superior services, such as "five-star high praise" and repurchase.

\subsubsection{Servicers' Conformation to the Modesty Maxim}

Fourthly, the Modesty Maxim means people who observe politeness principle will try their best to minimize compliments to self and find faults with self as much as possible. In other words, in the process of transaction, servicers should take more responsibilities and look into their conducts constantly on their own initiatives. As a matter of fact, the Modesty Maxim has the same effect with the Approbation Maxim when used—on transactions with principle paying customers compliments as much as possible and finding faults with servicers as much as possible. But in the real deal, the cases that servicers criticize themselves seriously are rare, and what they often do is to extend a formal apology and take some remedial measures to solve the problems. 
Example 4:

\begin{tabular}{lll}
\hline Message number & Text & Translation \\
\hline 1 & Servicer: & Servicer: \\
& 具体的话需要关注下订单信息 & You need to concern the order information for something specific. \\
& Customer: & Customer: \\
& 噢 & Oh! \\
& Servicer: & Servicer: \\
& 表情符号/握手 & Emoticon/Shaking hands \\
& Customer: & Customer: \\
& 很失望, 贴膜, 手机壳都到了, 白买 & I'm very disappointed and I have received the phone shell and film. I \\
& 了 & regret it. \\
& Servicer: & Servicer: \\
& 很抱歉给您带来了这样的购物体验。 & I am sorry to bring you such a shopping experience. Emoticon/Rose \\
& 表情符号玫瑰 & \\
& Servicer: & Servicer: \\
& 中午好 又被人追着打。午休也要买 & Good afternoon, I was chased again. You can buy everything during the \\
& 买买! 购物遇到问题, 记得点击底部 & midday rest! If you have some problems when shopping, remember to \\
& 快捷按钮或直接输入问题, JIMI 立即 & click the shortcut button at the bottom or input the question directly, and \\
& 来帮您哦。 & JIMI will help you immediately. \\
\hline
\end{tabular}

... I was angry with the servicer. Maybe I should be tolerant, because the servicer had said sorry to me. But the sorry couldn't solve the problem, and the servicer didn't take any measures...I won't come to this shop again anyway... [Ms. Zhao]

In this case, the servicer just says sorry but has no specific remedial measures. If the customer doesn't want to look for unnecessary troubles, he or she may accept the servicer's apology and concludes the deal, however, if the customer doesn't take this problem lying down, only one "sorry" can't satisfy the customer. What's worse, the fame of the servicer and the shop and the performance of the shop can be subjected to bad influences. Therefore, in the event of the servicers could take the Modesty Maxim at the right time, there will be more incomes than expenses.

\subsubsection{Servicers' Conformation to the Agreement Maxim}

Fifthly, the Agreement Maxim means people who observe politeness principle will try their best to minimize disagreement with other people and express agreement with other people as much as possible. In other words, in the process of communication between servicers and customers, both sides should endeavor to avoid or decrease the head-on confrontation.

Example 5:

\begin{tabular}{lll}
\hline Message number & Text & Translation \\
\hline 1 & Customer: & Customer: \\
& 钱什么时候到账 & When will the money put into my account? \\
& Servicer: & Servicer: \\
& 24 小时之内 & Within 24 hours. \\
3 & Servicer: & Servicer: \\
& 好吗亲亲 & Ok? My darling. \\
4 & Customer: & Customer: \\
& 你如果为难就别处理了, 我找拼多 & If you are in trouble, you needn't to deal with it any more. I will seek the \\
& 多介入 & help of Pinduoduo. \\
5 & Servicer: & Servicer: \\
& 好吧 & Alright. \\
6 & Customer: & Customer: \\
& 对你们卖家我无话可说, 快递太气 & I have nothing to complain about you seller, but the express delivery \\
& 人 & makes me so angry. \\
7 & Servicer: & Servicer: \\
& 好的吧 & Well \\
& Servicer: & Servicer: \\
& 已经帮亲亲退款了 & I have helped to refund your money, darling. \\
\hline
\end{tabular}


...If the servicer hadn't agreed to refund, I would have complained them. Even though, I have some prejudice against this shop now... [Mr. Li]

As shown in example 5, it is obvious that the customer is very angry, and fortunately, the servicer strictly observes the Agreement Maxim trying his or her best to avoid the head-on confrontation with the customer and solves the problem smoothly, if not, the fame of the servicer and the shop and the performance of the shop can be subjected to awful influences. From this we can conclude that it is significant that servicers take the Agreement Maxim at the right time.

\subsubsection{Servicers' Conformation to the Sympathy Maxim}

Sixthly, the Sympathy Maxim means people who observe politeness principle will try their best to minimize antagonism with other people and enhance mutual understanding. In other words, in the process of communication between servicers and customers, both sides should endeavor to understand each other and be magnanimous. As a matter of fact, the Sympathy Maxim has the same effect with the Agreement Maxim when used - carry on transactions with principle avoiding or decreasing the head-on confrontation and thinking being in each other' s perspective. At the same time, what the Sympathy Maxim stresses is the understanding of each other.

Example 6:

\begin{tabular}{lll}
\hline Message number & Text & Translation \\
\hline 1 & Customer: & Customer: \\
& 我没有收到任何消息好嘛 & I didn't receive any message, OK? \\
& Customer: & Customer: \\
& 5 天了, 亲 & I have bought it for five days, my darling! \\
3 & Servicer: & Servicer: \\
& 亲亲您不要着急哈, 这边联系催促快 & Please take it easy, darling. We will contact and urge express \\
& 递, 麻烦亲亲稍等哦 & delivery. Please wait a moment, darling. \\
4 & Servicer: & Servicer: \\
& 给您核实催促派送哈 & We will verify and urge delivery for you. \\
5 & Customer: & Customer: \\
& 所以鞋子现在已经不需要了。 & So, I don't need the shoes any more. \\
6 & Customer: & Customer: \\
& 不用了, 请退回吧。 & No, send them back, please. \\
\hline
\end{tabular}

... At that time, I had left the place where the shoes would be sent, so I had to return it and I was also very tough. If not, I didn't do that for the servicer's comfort and measures... [Mr. Shao]

In this communication, when the customer consults the express delivery in an anxious mood, the servicer not only comforts the customer, but also takes some measures immediately. What the servicer has said and done expresses that, in the communication between the servicer and customer, the servicer is sensitive to the mood of the customer and understands the feeling of the customer, if not, the fame of the servicer and the shop and the performance of the shop can be subjected to terrible influences. From this, we can conclude that it is significant that the servicers take the Sympathy Maxim at the right time.

\subsection{Discourse Analysis of Customers' Conformation to Politeness Principle}

In this section, the present study analyzes the expression of customers' discourses conformation to Agreement Maxim and Sympathy Maxim respectively through analyzing the concrete examples, and generalizes the current situation and reasons of customers' use of the six maxims of politeness principle.

\subsubsection{Customers' Conformation to the Agreement Maxim}

The Agreement Maxim means people who observe politeness principle will try their best to minimize disagreement with other people and express agreement with other people as much as possible. In other words, in the process of communication between servicers and customers, both sides should endeavor to avoid or decrease the head-on confrontation. 
Example 7:

\begin{tabular}{lll}
\hline Message number & Text & Translation \\
\hline 1 & Customer: & Customer: \\
& 我的快递是不是被不小心丢在 & I wonder whether my express delivery has been thrown into some little \\
& nook carelessly and can't be found out. \\
2 & Customer: & Customer: \\
& 表情符号/黑脸 & Emoticon/Black face. \\
3 & Servicer: & Servicer: \\
& 快递走不了 & The goods can't be transported normally. \\
4 & Servicer: & Servicer: \\
& 雪太厚 & The snow is too thick. \\
5 & Servicer: & Servicer: \\
& 一会去看看邮政能行不 & I will affirm whether the EMS can work normally, later. \\
6 & Servicer: & Servicer: \\
& 表情符号/可爱 & Emoticon/Lovely. \\
7 & Customer: & Customer: \\
& 好的谢谢 & Ok, thank you. \\
\hline
\end{tabular}

...Although I was very angry, the servicer wasn't the one to be blame for the trouble caused by the weather. As we all know, there usually are many uncontrollable factors in life... [Ms. Yan]

As is shown in example 7, although the logistics has been delayed, the customer still expresses thanks to the servicer after learning about the reason, from which we can find that customers usually understand servicers and minimize disagreement with them. Therefore, from what we have talked above, we can conclude that customers usually observe the Agreement Maxim.

\subsubsection{Customers' Conformation to the Sympathy Maxim}

The Sympathy Maxim means people who observe politeness principle will try their best to minimize antagonism with other people and enhance mutual understanding. In other words, in the process of the communication between servicers and customers, both sides should endeavor to understand each other and be magnanimous. As a matter of fact, the Sympathy Maxim has the same effect with the Agreement Maxim when used - carry on transactions with principle avoiding or decreasing the head-on confrontation and thinking being in each other' $s$ perspective. At the same time, what the Sympathy Maxim stresses is the understanding of each other.

Example 8:

\begin{tabular}{lll}
\hline Message number & Text & Translation \\
\hline 1 & Servicer: & Servicer: \\
& 您看下安装视频有什么不懂的可以 & You can watch the video about how to install the baby carriage. Contact \\
& 直接联系我们哦 & us directly, if you have questions. \\
& Customer: & Customer: \\
& 好的, 已经好了 & Ok, I have done it. \\
3 & Servicer: & Servicer: \\
& 好的亲 & Ok, my darling. \\
4 & Servicer: & Servicer: \\
& 满意的话给我们个好评支持一下吧 & If you are satisfied, please give us a favorable comment to support us. \\
& Customer: & Customer: \\
& 我刚才进店了, 不知道怎么评 & I've just browsed the website of your store, but I don't know how to \\
& & make a comment. \\
6 & Servicer: & Servicer: \\
& 去我的订单里看 & In “my order” \\
7 & Servicer: & Servicer: \\
& 确认收货 & Confirm receipt of the commodity. \\
\hline
\end{tabular}

...The servicer was friendly and accommodating. She had helped me, so I had no reason to refuse her request and, after all, no one works easily... [Mr. Ding]

In the communication of example 8, when the servicer asks the customer to give them a favorable comment after helping the customer solve problems, the customer gladly agrees, from which we know that customers and 
servicers aren't always hostile and customers usually understand servicers in normal conditions. Therefore, from what we have talked above, we can conclude that customers usually observe the Sympathy Maxim.

\subsubsection{Summary of Customers' Conformation to Politeness Principle}

Among the data the author has collected, there are very few cases that the customers' discourses conform to Tact Maxim, Generosity Maxim, Approbation Maxim and Modesty Maxim in e-business instant communication, and usually what customers observe is Agreement Maxim and Sympathy Maxim, nevertheless, they will violate Agreement Maxim and Sympathy Maxim on special occasions. The reasons why the circumstance occurs are as follows:

Firstly, the communicating purposes of customers are to learn about information of commodities, choose the most appropriate commodity and let servicers help them to solve the problems which they have met with during the process of their shopping.

Secondly, all the customers hope to have a wonderful shopping experience, have a strict demand to the quality and speed of the service and commodity and have particular requirements for the attitudes of the servicers. Once there is something not satisfying them, they will argue with the servicers without hesitation.

Thirdly, under certain circumstances, such as unsatisfied requirements, the wrong commodity sent, etc., the customers tend to violate Agreement Maxim and Sympathy Maxim.

\subsection{Discourse Analysis of Servicers' Violation of Politeness Principle}

In this section, the present study generalizes the current situation and reasons of servicers' use of the six maxims of politeness principle.

\subsubsection{Situation of Servicers' Violation of Politeness Principle}

Among the data the author has collected, there is no case that the servicers' discourses violate politeness principle in e-business instant communication, although sometimes the language of customers is impolite and thrusting, in other words, the servicers observe politeness principle in a strict way under any circumstances.

\subsubsection{Summary of Servicers' Violation of Politeness Principle}

The reasons why servicers observe politeness principle in such a strict way are listed as follows: First and foremost, communicating with customers friendly and passionately is the basic requirement to the online sales customer servicers. In other words, the particularity of occupation has determined the special requirement to the attitude of related workers. If not, it is difficult to keep the smooth communication between servicers and customers. Secondly, the human nature is a strange thing. Most of people of the society won't be afraid of the people who have ill temper, who are brutal and who are impolite, but frighten and revere those who are gentlemanlike and knowledgeable. And then, the merchants utilize this character to make trade smoothly progressed.

\subsection{Discourse Analysis of Customers' Violation of Politeness Principle}

In this section, the present study focuses on the customers' violation to politeness principle's six maxims.

\subsubsection{Customers' Violation of the Tact Maxim}

First of all, the Tact Maxim means people who observe politeness principle will try their best to minimize disadvantageous information to others and benefit others as much as possible. In other words, what the customers do or say is in the servicers' shoes, considers the gain and loss of the servicers and finally satisfies the servicers. Obviously, it doesn't conform to the common sense. 
Example 9:

\begin{tabular}{lll}
\hline Message number & Text & Translation \\
\hline 1 & Customer: & Customer: \\
& 不好意思, 表情符号/大笑, 因为跟别人合买 & Sorry, Emoticon/Laugh, I have bought another brand with other \\
& 了其他的, 如果再买的话再来买你们的, 不 & friends, and I will buy your commodity if I need it again. I'm so \\
& 好意思, 打扰了 & sorry to bother you. \\
2 & Servicer: & Servicer: \\
& 没事 & Nothing. \\
3 & Servicer: & Servicer: \\
& 小事情 & Never mind \\
4 & Servicer: & Servicer: \\
5 & 其他人买了? & Have other people bought it? \\
& Customer: & Customer: \\
& 额, 她买了其他粉, 不是你们家的, 不好意 & Emmm, I'm so sorry that she has bought the milk powder from \\
& 思实在 & other shops. \\
& Servicer: & Servicer: \\
7 & 没事 & Never mind. \\
& Servicer: & Servicer: \\
\hline
\end{tabular}

...I knew what I had done causing much trouble to the servicer, but as a customer I had the right to buy or return the commodity... [Ms. Gu]

From the communication, we can know that what the customer says isn't the consideration for the servicer, but is conducted by his or her demand. By analyzing the discourses of e-business instant communication from the perspective of politeness principle, the present study finds that the communicating purposes of customers are to learn about the information of commodities, choose the most appropriate commodity and let servicers help them to solve the problems which they have met with during the process of their shopping. According to what we have talked above, we can conclude that the language of customers violates the Tact Maxim.

\subsubsection{Customers' Violation of the Generosity Maxim}

Secondly, the Generosity Maxim means people who observe politeness principle will try their best to minimize advantageous information to self and benefit self as little as possible. In other words, what customers do or say isn't in their own shoes, doesn't consider the gain and loss of themselves and finally satisfies servicers and further closes the deal smoothly. As a matter of fact, the Generosity Maxim has the same effect with the Tact Maxim when used - carry on transactions with principle making servicers benefit a lot and letting customers gain little.

Example 10:

\begin{tabular}{lll}
\hline Message number & Text & Translation \\
\hline 1 & Customer: & Customer: \\
& 这个款啥时候会出加线的? & When will this kind of clothes added with velvet be available? \\
& Servicer: & Servicer: \\
3 & 亲, 你好 & Hello, my darling \\
& Servicer: & Servicer: \\
4 & 在的哈 & I am online \\
& Servicer: & Servicer: \\
5 & 这个可能要晚一些的时候 & This may be available later \\
& Servicer: & Servicer: \\
6 & 暂时的话, 还是会以不加线为主的。 & Temporarily, we will focus on clothes without the velvet. \\
& Customer: & Customer: \\
& 吃吃, 好吧 & Emmm, alright. \\
8 & Servicer: & Servicer: \\
& 因为加线的话还是比较厚实的 & Because the clothes added with velvet are relatively thick. \\
9 & Servicer: & Servicer: \\
& 秋天穿不是特别合适 & It isn't particularly suitable to wear in autumn \\
& Servicer: & Servicer: \\
& 亲可以关注我们的店铺, 上新都会有 & Darling, you can concern our shop, and you will be informed if there \\
& 通知的 & are some new arrivals. \\
\hline
\end{tabular}




\section{...As a customer, I must know clearly about what I want to buy... [Ms. Yang]}

From the communication, we can know that the purpose of the customer to communicate with the servicer is to acquire more information benefitting herself or himself. By analyzing the discourses of e-business instant communication from the perspective of politeness principle, the present study knows that the communicating purposes of customers are to learn about information of commodities, choose the most appropriate commodity and let servicers help them to solve the problems which they have met with during the process of their shopping. According to what we have talked above, it can be concluded that the language of customers violates the Generosity Maxim.

\subsubsection{Customers' Violation of the Approbation Maxim}

Thirdly, the Approbation Maxim means people who observe politeness principle will try their best to minimize criticism to other people and pay other people compliments as much as possible. In other words, even if there are some problems caused by errors or omissions of servicers, customers should be magnanimous and good-mannered, forgiving servicers' faults and errors and not bothering about too much of the gain and loss. What's more, it will be better if customers can praise servicers at the proper moment.

\section{Example 11:}

\begin{tabular}{|c|c|c|}
\hline Message number & Text & Translation \\
\hline \multirow[t]{2}{*}{1} & Customer: & Customer: \\
\hline & 是的。 & Yes. \\
\hline \multirow[t]{2}{*}{2} & Customer: & Customer: \\
\hline & 你们给我补的这个我用不上 & The commodity you have made up for me is of no use to me. \\
\hline \multirow[t]{2}{*}{3} & Servicer: & Servicer: \\
\hline & 好的, 我这边看下。 & OK, I will check up. \\
\hline \multirow[t]{2}{*}{4} & Customer: & Customer: \\
\hline & 真服你了。 & I have nothing to say. \\
\hline \multirow[t]{2}{*}{5} & Servicer: & Servicer: \\
\hline & 可能是工厂那边发错了 & The factory may have sent the wrong commodity. \\
\hline \multirow[t]{2}{*}{6} & Customer: & Customer: \\
\hline & 那你说这次该怎么办? & So, how do you deal with it? \\
\hline \multirow[t]{2}{*}{7} & Customer: & Customer: \\
\hline & 现在这个东西我也用不上 & Now, this thing is of no use to me. \\
\hline \multirow[t]{2}{*}{8} & Customer: & Customer: \\
\hline & 这两个价钱也不一样吧 & The prices of the two commodities aren't the same, are they? \\
\hline \multirow[t]{2}{*}{9} & Servicer: & Servicer: \\
\hline & 那只能是退回。 & The only way is to return it. \\
\hline \multirow[t]{2}{*}{10} & Customer: & Customer: \\
\hline & 这个邮费谁出啊 & Who pays the postage? \\
\hline \multirow[t]{2}{*}{11} & Servicer: & Servicer: \\
\hline & 我们出 & We will undertake. \\
\hline \multirow[t]{2}{*}{12} & Customer: & Customer: \\
\hline & 那, 还给我补不补货啦 & Then, will you post a replacement for me? \\
\hline
\end{tabular}

... I think every customer hopes to have a wonderful shopping experience and everyone will protect his interest. What's more, sometimes everyone should be responsible for his own mistakes... [Ms. Cao]

From the above example 11, it is known that the customer doesn't minimize criticism to the servicer, but questions the servicer in a fierce mood. By analyzing the discourses of e-business instant communication from the perspective of politeness principle, the present study knows that all the customers hope to have a wonderful shopping experience, have a strict demand to the quality and speed of the service and commodity and have particular requirements for the attitude of servicers. Once there is something not satisfying them, they will argue with the servicers without hesitation. According to what we have talked above, it can be concluded that the language of customers violates the Approbation Maxim.

\subsubsection{Customers' Violation of the Modesty Maxim}

Fourthly, the Modesty Maxim means people who observe politeness principle will try their best to minimize compliments to self and find faults with self as much as possible. In other words, in the process of transaction, customers should take more responsibilities and look into their conducts constantly on their own initiatives. As a 
matter of fact, the Modesty Maxim has the same effect with Approbation Maxim when used-carry on transactions with principle paying servicers compliments as much as possible and finding faults with customers as much as possible. But in the real deal, the cases in which the customers criticize themselves seriously are rare.

Example 12:

\begin{tabular}{lll}
\hline Message number & Text & Translation \\
\hline 1 & Servicer: & Servicer: \\
& 以页面为准呢 & It depends on the information on the page. \\
Customer: & Customer: \\
& 三个表情符号/无语 & There are three emoticons/speechless. \\
3 & Customer: & Customer: \\
& 一个月? & One month? \\
& Customer: & Customer: \\
5 & 为甚要等一个月? & Why should I wait for it for a month? \\
& Customer: & Customer: \\
6 & 快点发货好吗? & Deliver the commodity quickly, OK? \\
& Servicer: & Servicer: \\
\hline
\end{tabular}

... It was my carelessness not to see the introduction clearly. However, emm, maybe it is usual that a customer consults with servicers... [Ms. Geng]

As is shown in example 12, the customer buys pre-sale product for his or her carelessness and the commodity only can be posted one month later. However, the customer directly argues with the servicer, ignoring his or her mistakes. What's more, the communicating purposes of customers are to learn about information of commodities, choose the most appropriate commodity and let servicers help them to solve the problems which they have met with during the process of their shopping. In other words, what customers say in the e-business instant communication just violates the Modesty Maxim.

\subsubsection{Customers' Violation of the Agreement Maxim}

Fifthly, The Agreement Maxim means people who observe politeness principle will try their best to minimize the disagreement with other people and express agreement with other people as much as possible. In other words, in the process of the communication between servicers and customers, both sides should endeavor to avoid or decrease the head-on confrontation.

Example 13:

\begin{tabular}{lll}
\hline Message number & Text & Translation \\
\hline 1 & Servicer: & Servicer: \\
& 这个我们真不清楚呢? & We really don't know about it. \\
& Customer: & Customer: \\
3 & 不知道怎么处理 & You don't know how to deal with it! \\
& Customer: & Customer: \\
& 我信息是不是给你了 & I have sent the information to you, right? \\
4 & Servicer: & Servicer: \\
5 & 可以给亲亲补发一件 & I can post you a replacement, my darling. \\
& Customer: & Customer: \\
6 & 打电话没有录音 & There is no answer when I call you. \\
& Servicer: & Servicer: \\
7 & 现在的这个包裹是回不去了 & Now, it's impossible for you to get the original package. \\
& Customer: & Customer: \\
& 不要了 & I don't want it anymore. \\
& Customer: & Customer: \\
& 请你搞清楚 & You should be clear about what has happened! \\
\hline
\end{tabular}

... Indeed, I had a bad attitude at that time. The servicer said that she didn't learn clearly and didn't know how to deal with the matter, which made me angry. If she didn't help me, who can I ask? So I was totally dissatisfied with her. I didn't have interest in shopping anymore, even though she sent me another commodity... [Mr. Gao]

As is shown in example 13, it is obvious that the customer is very angry, and violates the Agreement Maxim. By analyzing the discourses of e-business instant communication from the perspective of politeness principle, the 
present study concludes that under certain circumstances, such as unsatisfied requirements, the wrong sent commodity, etc., customers tend to violate the Agreement Maxim, but customers usually observe the Agreement Maxim, too.

\subsubsection{Customers' Violation of the Sympathy Maxim}

Sixthly, the Sympathy Maxim means people who observe politeness principle will try their best to minimize antagonism with other people and enhance mutual understanding. In other words, in the process of communication between servicers and customers, both sides should endeavor to understand each other and be magnanimous. As a matter of fact, the Sympathy Maxim has the same effect with Agreement Maxim when used - carry on transactions with principle avoiding or decreasing the head-on confrontation and thinking being in each other's perspective. At the same time, what the Sympathy Maxim stresses is the mutual understanding.

Example 14:

\begin{tabular}{|c|c|c|}
\hline Message number & Text & Translation \\
\hline \multirow[t]{2}{*}{1} & Customer: & Customer: \\
\hline & 怎么还不发货 & Why don't you post the commodity to me? \\
\hline \multirow[t]{2}{*}{2} & Servicer: & Servicer: \\
\hline & $\begin{array}{l}\text { 亲, 每个订单都将根据付款时间来安排发 } \\
\text { 货, 您拍下付款后我们会尽快为您安排, } \\
\text { 麻烦您耐心等待一下哈, 表情符号/微笑。 } \\
\text { 如订单中包含预定款, 发货时间以预定时 } \\
\text { 间为主哦 }\end{array}$ & $\begin{array}{l}\text { My darling, each order will be arranged to be posted according to } \\
\text { the order time. We will arrange the delivery as fast as we can, after } \\
\text { you pay for the order, and please wait in patience. Emoticon/Smile. } \\
\text { If the order contains a pre-order, the delivery time is based on the } \\
\text { scheduled time. }\end{array}$ \\
\hline \multirow[t]{2}{*}{3} & Servicer: & Servicer: \\
\hline & $\begin{array}{l}\text { 亲, 我们会按您拍下的时间顺序安排发货 } \\
\text { 哦。 }\end{array}$ & $\begin{array}{l}\text { Darling, we will arrange the delivery for you according to your } \\
\text { order time. }\end{array}$ \\
\hline \multirow[t]{2}{*}{4} & Customer: & Customer: \\
\hline & 说的 $24 \mathrm{~h}$ 内发货的。 & You have said that you would post the commodity within 24 hours. \\
\hline \multirow[t]{2}{*}{5} & Customer: & Customer: \\
\hline & 什么意思？那什么时候能发货？ & What do you mean? When will you post the commodity to me? \\
\hline \multirow[t]{2}{*}{6} & Servicer: & Servicer: \\
\hline & 亲 24 小时还没到哦 & Darling, it's less than 24 hours now. \\
\hline \multirow[t]{2}{*}{7} & Servicer: & Servicer: \\
\hline & 不出意外下午哦。 & $\begin{array}{l}\text { If everything goes successfully, we will post the commodity to you } \\
\text { in the afternoon. }\end{array}$ \\
\hline
\end{tabular}

... I was anxious for using the commodity at that time and hoped they could post the commodity as quickly as possible. Maybe I wasn't the only one who bought this product and I indeed urged the servicer many times within 24 hours... [Mr. Lu]

In this communication, the customer takes a tough stance and urges the servicer to post the commodity, although it hasn't exceeded the limitation. What the customer has done violates the Sympathy Maxim. What's more, by analyzing the discourses of e-business instant communication from the perspective of politeness principle, the present study finds that under certain circumstances, for instance, unsatisfied requirements, the wrong sent commodity, etc., customers are inclined to violate the Sympathy Maxim, and usually, customers observe the Sympathy Maxim as well.

\section{Conclusion}

From the data analysis above, it can be found that although customers sometimes don't observe politeness principle, but servicers observe politeness principle all the time and servicers' politeness can calm down customers who are angry for some reasons occurring during the purchasing, promote the close of deals and even enhance the reputation and performance of the company. The findings are summarized as follows:

On the one hand, servicers strictly observe the six maxims of politeness principle with no violations in e-business instant communication. Even so, there will be different results for other reasons. Firstly, in the absence of accidents, in other words, commodity, logistics and other related things are all right, servicers' conformation to politeness principle can make the communication and trade better. Secondly, if there are some accidents and customers observe Agreement Maxim and Sympathy Maxim, and at this time servicers and customers understand each other, servicers' conformation to politeness principle can promote to solve problem and close deals. Thirdly, if there are some accidents and customers violate any of Agreement Maxim and Sympathy Maxim, deals can't go smoothly even if servicers observe politeness principle totally. 
On the other hand, customers go against Tact Maxim, Generosity Maxim, Approbation Maxim and Modesty Maxim and usually comply with Agreement Maxim and Sympathy Maxim, nevertheless, they will violate Agreement Maxim and Sympathy Maxim on special occasions in e-business instant communication. What's more, customers' violation to any maxim of Tact Maxim, Generosity Maxim, Approbation Maxim and Modesty Maxim can't affect the process of deals; but violation to any maxim of Agreement Maxim and Sympathy Maxim can hinder the process of deals, in other words, customers' conformation to Agreement Maxim and Sympathy Maxim can speed up the close of deals.

Therefore, for servicers, while observing politeness principle, they should try their best to avoid the happening of accidents and study how to deal with customers' violation to Agreement Maxim and Sympathy Maxim successfully. And for customers, even if there are accidents, they should try their best to observe Agreement Maxim and Sympathy Maxim, the reason for which is that usually servicers will help customers solve any related problems and customers' conformation to Agreement Maxim and Sympathy Maxim can speed up the close of deals; if not, deals will be failing.

However, there are some limitations that need to be addressed by future research. The present study just analyzes the application of politeness principle's six maxims of servicers and customers in e-business instant communication, and its influences on e-business transactions, and further concludes what servicers and customers should do to promote the completion of deals. It's beneficial to consider whether the application of emoticons related to politeness principle, the speed of response and the application of punctuation in e-business instant communication will affect the process of deals or not.

\section{Author Biography}

Tingting Guo received her PhD in Business English Studies from GuangDong University of Foreign Studies. Her research interests include discourse analysis, business communication studies, forensic linguistics and comparative study of English and Chinese. She currently works in the Postdoctoral Research Station of Chinese Language and Literature of School of Liberal Arts of Zhengzhou University.

\section{Acknowledgments}

The research is sponsored by Ph. D Research Programme of Zhongyuan University of Technology [No. 34110495], and the 13th Five-year Key Project Cultivation Programme of School of Foreign Languages of Zhongyuan University of Technology.

The authors' sincere appreciation goes to the anonymous peer-reviewers and the editor for their useful and enlightening comments and suggestions concerning further improvement of this paper. And our heartfelt gratitude also goes to the assistant editor for her timely mail confirmation and supply of help.

\section{References}

Brown, G., Gillian, B., \& Yule, G. (1983). Discourse analysis. Cambridge University Press. https://doi.org/10.1017/CBO9780511805226

Felemban, F. H. (2012). Building up learners' communicative competence: the politeness principle. Procedia Social and Behavioral Sciences, 46, 70-76. https://doi.org/ 10.1016/j.sbspro.2012.05.070

Grice, H. P. (1975). Logic and conversation. In P. Cole \& J. Morgan (Eds.), Syntax and semantics: speech acts (Vol. 3, pp. 41-58). New York: Academic Press.

Gu, Y. G. (1992). Politeness, pragmatics and culture. Foreign Language Teaching and Research, 4, 10-17.

Guo, T., \& Zhu, W. (2009). The integrative nature of BE teaching: knowledge and skills. Asian Social Science, 5(11), 72-75. https://doi.org/10.5539/ass.v5n11p72

Holgraves, T., \& Joong-nam, Y. (1990). Politeness as universal: Cross-cultural perceptions of request strategies and inferences based on their use. Journal of Personality and Social Psychology, 59(4), 719-729. https://dx.doi.org/10.1037/0022-3514.59.4.719

Huang, G. W., \& Xu, J. (2006). Analysis on discourse and text. Foreign Languages and Foreign Language Teaching, 10, 1-6.

Leech, G. (1983). Principles of pragmatics. London: Longman Group Limited.

Levinson, S. C. (1983). Pragmatics. Cambridge: Cambridge University Press. https://doi.org/10.1017/CBO9780511813313

Lin, L. J. (2011). Discussion on the use of politeness principle in business communication. Journal of Jiamusi 
Education Institute, 11, 18-19.

Lin, X. Y. (2007). The application of instant communication in e-business websites. Entrepreneur World, 10, $212-213$.

Ma, S. Y., \& Zhao, J. F. (2007). Politeness principle in pragmatics-A golden key to the success of business. Market Modernization, 490, 85-86.

Shen, L. L. (2013). The application of politeness strategies in business communication. Human Resource Management, 9, 239-241.

Sun, Y. B., \& Tian, Y. (2012). The application of cooperative principle and politeness principle in verbal communication. Testing and Evaluation (College English Teaching and Research), 5, 30-33.

Wan, D. (2016). Analysis on the application of instant communication tools in network marketing. Journal of Green Science and Technology, 22, 179-180.

Wu, J. (2003). The politeness principle in business English. Chinese Science \& Technology Translators Journal, $1,31-33$.

Zhou, Y. L. (2007). Discussion on the influence of politeness principle on cross-cultural communication. China Science \& Technology Information, 16, 153-154.

Zhu, Y. S. (2003). Fifty years of discourse analysis: prospects and review. Journal of Foreign Languages, 3, 4350 .

\section{Copyrights}

Copyright for this article is retained by the author, with first publication rights granted to the journal.

This is an open-access article distributed under the terms and conditions of the Creative Commons Attribution license (http://creativecommons.org/licenses/by/4.0/). 